（イ）工数原単位 (工/E.M. C. t ) (亜鉊電解部門)

\begin{tabular}{r|r|r|r|r|r|r|r|r|r|r|r|}
\hline \hline 31 年 & 32 年 & 33 年 & 34 年 & 35 年 & 36 年 & 37年 & 38 年 & 39 年 & 40 年 & 41 年 \\
\hline 3.5 & 2.6 & 2.6 & 2.3 & 2.2 & 2.1 & 1.5 & 1.6 & 1.3 & 1.1 & 1.1
\end{tabular}

（ウ）亚鉛採收率（％）（正颌雱解部門）

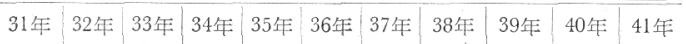

\begin{tabular}{l|l|l|l|l|l|l|l|l|l|l|}
\hline 91.7 & 91.6 & 94.2 & 94.9 & 94.9 & 94.7 & 94.9 & 94.2 & 94.0 & 94.3 & 94.4 \\
\hline
\end{tabular}

その主なものを挙げれば第10表のとおりである。

\section{7. 結言}

以上は神岡における最近 10 年間の鉛製鍊および业鉛製 鍊の推移とその進歩について概要を記述した。

今後はさらに改善努力積名重社て技術の向上と原価 低減に努力したい所存である。本報告を終るにあたり， 当所の生产規模の桩大と生産技術の確立に尽力された先 輩各位ならびにご支援在いただいた関係者各位に対し深 甚なる敬意と感謝の意老表わ寸次第である。

\title{
三日市製錬所の亚鉛製錬
}

\section{Zinc Smelting and Refining at Mikkaichi Smelter}

正会員荻 原 研 郎* Kenrō OGIHARA

\section{1. 緒言}

当所は, 雄大な北アルプス老背景 に唇気楼で名高い富山湾に面した黒 部市の一角に位置し，昭和28年 9 月 に亜鉛製鍊ならびにこれ机付带する 事業在行なうことを目的として，日 本鉱業株式会社と日窒鉱業株式会社 との共同出資によつて三日市製鍊株 式会社として発足した。

新会社設立後直ちに建設に入り, 昭和29年12月末に 1 号電熱蒸留炉 (以下電炉と略す) の 操業老開始乙，300t/月の蒸留西鉛老生産して以来 12 年 尔経過し，現在では徒業員数 452 名で常時 7 炉を操業し 月 $8,100 \mathrm{t}$ (内型西鈖 $4,500 \mathrm{t}$ ) 在生産するにいたつた。

なお，昭和36年 2 月に注力ドミウム工場，37年4月に は精留工場，38年6月には合金工場の操業を開始し，現 在カドミウム $20 \mathrm{t}$, 最純型垔鉛 $2,600 \mathrm{t}$ ，ダイカス卜用 亜鉛合金塊およびメッキ用陽極1,000 t を生産している。

この間昭和36年 2 月に，亜鉊精鉣の委託ばい焼先であ つた敦賀化学工業株式会社と合併して社名を日本製鍊株 式会社と改め,さらに，40年 2 月に注親会社の日本鉱業 株式会社に吸収合併され，日本鉣業唯一の亜鉛製鍊部門 となつた。

つぎに当所の主要製品ごとにその変遷と現状について 述べる。

\footnotetext{
* 日本釷栄祩式会社三日市慗鍄所副所艮
}

\section{2. 蒸留覀鉛部門}

\section{$2 \cdot 1$ ばい焼}

創業当初の第1期計画では帚鉛生産量を450t/月とし, 亜鉊精鉱のばい燒は日産化学株式会社富山工場に委託し ていた。しかし，当時の経済状勢では400 500t/月程度 の製錬規模で注採算点に達しないので早急な生産量の搪 大が必要となり，1,000t/月体制の一環として前記，日 座化学のほ加に昭和31年 7 月に敦賀化学工業株式会社と も委託ばい焼契約圭行なつた。この委託ばい焼の2本建 ては, 約 1 年閒続いたが32年 6 月に敦賀のばい焼能力の 增加を機会に日産化学との契約を解消し，以来，全量を 敦賀で処理することとなつた。

敦賀工場に括けるばい焼工程は，B．A. S . F.式流動 炉による西鉛精鈖のばい燒と，ばい焼炉ガスからのケミ コ式による接触硫酸製造とからなり，現在従業員92名で B. A. S. F. 式流動汭い焼炉 5 基を操業して，9,800t/ 月の亜鉛焼鉣と $10,500 \mathrm{t} /$ 月 ( $100 \%$ 換算) の濃硫酸老生 
産している。過去10年間における年度別の硫酸生産量の 推移は第 1 表のとおりである。

第 1 表 年度別硫酸生産量 (100\%猴算)

\begin{tabular}{c|c|c|c|c|c}
\hline \hline 年 度 & 32 & 33 & 34 & 35 & 36 \\
\hline 生産量 $(\mathrm{t})$ & 21,000 & 21,100 & 26,100 & 37,300 & 56,200 \\
\hline \hline 年 度 & 37 & 38 & 39 & 40 & 41 \\
\hline 生产量 $(\mathrm{t})$ & 61,800 & 72,800 & 82,300 & 101,400 & 127,200 \\
\hline
\end{tabular}

受け入れ亜鉛精鉱は，社内鉱 $72.4 \%$, 社外鉱 $7.1 \%$, 輸入鉱 $20.5 \%$ (41年下期) の比率で, 他社と比較して社 内鉱の占める比率がきわめて高く, 安定したしかも恵ま れた原料事情といえよう。産出焼鉱は北陸線経由で敦賀 ・黒部間をピストン輸送される。41年下期における受け 入れ亜鉛精鉱と使用亜鉛燒鉱の量および成分は第 2 表の とおりである。

第 2 表 亜鉛精鉱扣よび焼鉱の主成分

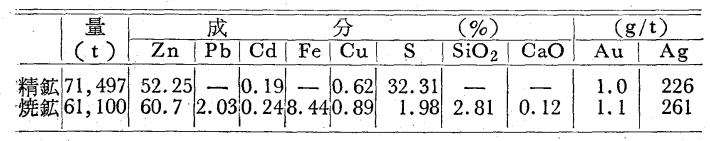

敦賀工場での特記事項としては，42年 7 月からばい焼 工程における排熱の回收活用方法として $2,200 \mathrm{~kW}$ の 発 電設備を完成し, 工場の使用電力を賄いコスト低減に大 きな貢献をしていることである。

\section{$2 \cdot 2$ 焼結}

燒結の目的は衆知のとおり, 電炉入装入する原料を適 当な電気抵抗を有し，被還元性がよく，堅固で難溶融性 の粒につくることで焼鉱中の $\mathrm{Pb}, \mathrm{Cd}, \mathrm{S}$ 等の不純分を除 去して，亜鉛地金への夾雑を防止するとともにこれらの 有価物を回収することにある。

工程は大別して焼結, 焼結塊の粉砕・整粒, 排ガス処 理およびその他の付帯工程とからなり現在約 $13,400 t / 月$ の焼鉱を処理して $16,600 \mathrm{t}$ のシンターを生産している。

1 号焼結機は, 1 号電炉が完成する約 3 力月前の昭和 29年 8 月に完成し同月 23 日から操業に入つた。これは, 三日市製錬所にはじめての「火」が入つた記念すべき日 である。2 号燒結機は，31年 3 月に 3 号電炉と同時に完 成し，ここに亜鉛地金生産量月当り $1,000 \mathrm{t}$ の体制がで きた。その後は蒸留亜鉛の生産量ののびにしたがつて焼 結能力の増強が図られるとともに, 焼結技術ならびに電 炉操業技術の向上等によつて現在でも 2 基操業で $8,100 \mathrm{t}$ の地金生産量に見合つた焼結塊を生産している。

この間に, 焼結排ガス中の煙灰からカドミウムの回収 が計画され, 昭和35年12月に 1 号コットレル，38年 4 月 に 2 号コットレルが完成し, 回収煙灰はカドミウム工場 の原料に供している。
焼結機は, 直線式ドワイトロイド型で 1 基当りの有効 吸引面積が $18.6 \mathrm{~m}^{2}$ で焼鉱の処理能力は時間当り $10 \mathrm{t}$ で ある。焼結原料は, 焼鉱のほかに焼結繰返鉱, 電炉から の繰返物, 工場全体からの捕集ダストその他で，このほ かに少量の粘結剤および補助燃料として粉コークスを添 加する。これらの調合割合は，お押むね焼鉱 $35 \%$, 焼結 繰返鉱 $52 \%$, 電炉繰返物 $5 \%$, ダストその他 $6 \%$ で, こ の調合物に6 7\%の水分を添加してパグミルで充分混和 したのち焼結機へ装入する。焼結機グレード上にはあら かじめベッテング材を敷き，その上に約 $24 \mathrm{~cm}$ の厚さに 調合物が装入され, 約 $1 \mathrm{~m} / \mathrm{min}$ の速度で進行し点火炉で $\mathrm{CO}$ ガスの燃焼フレームで鉱層上部に点火され下向吸引 によつて焼結される。焼結塊は焼結機先端のシングルロ ールクラッシャで砕かれ，さらにブレーキクラッシャ， ロールクラッシャ，振動ふるい等を設備した整粒工場で 6〜25mmに整粒され, 整粒シンター（第 3 表）として電 炉工場へ送られる。

第3 表 産出シンターの主成分例

\begin{tabular}{c|c|c|c|c|c|c|c|c}
\hline 成 分 & $\mathrm{Zn}$ & $\mathrm{Fe}$ & $\mathrm{SiO}_{2}$ & $\mathrm{Cu}$ & $\mathrm{Pb}$ & $\mathrm{Cd}$ & $\mathrm{Au}$ & $\mathrm{Ag}$ \\
\hline$\%$ & 57.4 & 8.32 & 6.60 & 0.89 & 1.23 & 0.04 & $\begin{array}{c}\mathrm{g} / \mathrm{t} \\
1.0\end{array}$ & $\begin{array}{c}\mathrm{g} / \mathrm{t} \\
173\end{array}$ \\
\hline
\end{tabular}

燒結原料調合割合は前で述べたとおりであるが，操業 当初から数年間は焼鉱に対する焼結繰返鉱の割合は 400 \%前後で，焼結歩留りが低く工程内の各所に不要な負荷 をかけていた。しかし現在では種々の努力と技術の進歩 によつて繰返比率を $150 \%$ にまて低下している。

燒結排为スは 1 基当り約 $55,000 \mathrm{Nm}^{3} / \mathrm{h}$ で排ガス中に は約 $2,000 \mathrm{ppm} の \mathrm{SO}_{2}$ と $3 \sim 5 \mathrm{~g} / \mathrm{Nm}^{3}$ のダストが含まれ ている。排ガスはダクトで調湿塔に導かれ水分約 $20 \%$, ガス温 $65 \sim 70^{\circ} \mathrm{C}$ 調整されたのち, コットレルへ送られ る。コットレルでダストが除かれた排ガスは石灰石を充 填した 2 基の中和塔に導かれ, 頂部から適量の散水をし て逆流中和洗浄を行ない，排ガス中の $\mathrm{SO}_{2}$ はこの中和塔 で $20 \mathrm{ppm}$ 以下に中和され大気へ放出される。

\section{$2 \cdot 3$ 蒸留}

当所が採用している製錬方式は，アメリカのセントジ ョセフレッド社が，1931年ジョセフタウン製錬所で亜鉛 華の製造を目的に開発した抵抗電熱式連続亜鉛蒸留法で ある。

セントジョセフでは, その後1936年に電熱蒸留炉から の亜鉛蒸気を連続的に凝縮するいわゆるウィートン・ナ ジャリヤン真空コンデンサを開発して，直接金属亜鉛を 製造することに成功した。セントジョセフ法の特色は, 電炉とコンデンサであつて，当所ではコンデンサについ てのみ技術導入し，その他は当時，すでに発表されてい た文献等を参考にして独自に設計したものである。 
工場の建設は，昭和28年12月に開始され29年12月に 1 号電炉を完成操業を開始し，逐年その技術の改善と規模 を拡充して，40年 4 月脱鉛炉，自動連続鋳造機の操業を 開始， 41 年 3 月に 8 号炉を完成後現在にいたつている。

電炉は，大別するとプレヒーター，給鉱機，炉本体， 排鉱機，コンデンサからなり，予熱機は内径 $860 \mathrm{~mm}$ の ロータリーキルン型で，ガスバーナとオイルバーナをそ れぞれ 1 基ずつ備えている。給鉱機は炉本体の頂部にあ つて炉体の子たを形成し，装入物が炉内平断面で環状に なるように装入する回転体である。

炉本体は全高約 $12 \mathrm{~m}$, 内容積約 $42 \mathrm{~m}^{3}$ で炉頂から約 $1 / 3$ の高さの部分にベーパーリングと称する亜鉛蒸気を取り 出すふくらみ部をもつたシャフト型で，炬体上下部には $305 \mathrm{~mm} \phi$ の電極が挿入してあり，上下対角線状に電流回 路を形成している。炉用変圧器は 1 極につき 1 台あり容 量は $540 \mathrm{kVA}$ で一次電圧 $3,300 \mathrm{~V}$, 二次電圧 160 ～320Vで 誘導電圧調整器を備えている。排鈗機は円形テーブル型 で電炉本体の直下で炉の底を形成し，回転しながら蒸留 残さいを排出している。なお，排鉱機は可変速モ一夕を 備えていて変速可能となつている。コンデンサは，外部 は波型厚鋼板で, カーボランダムレンガで内張りした断 面が卵型をした長さ約 $4 \mathrm{~m}$ の字管型で，熔体亜鉛を冷 却するクーリング・タッピング・ウエルと対になつてい て 2 本の連結管で連結されている (第 1 図参照)。

電炉は，コークスを導体とした抵抗炉であるから装入 物のシンターおよびコークスの混合比率およびそれぞれ の粒度分布, 装入量, 電極の挿入長さ, 電力量等が炉温 および温度分布を左右し，炬の成績に大きく影響する。

通常, シンターおよびニークスの混合比率は, 容積比 で約1：1にしているが，シンター中の亜鉛含有率および 炉内の電気抵抗等を考慮のうえ決定している。シンター

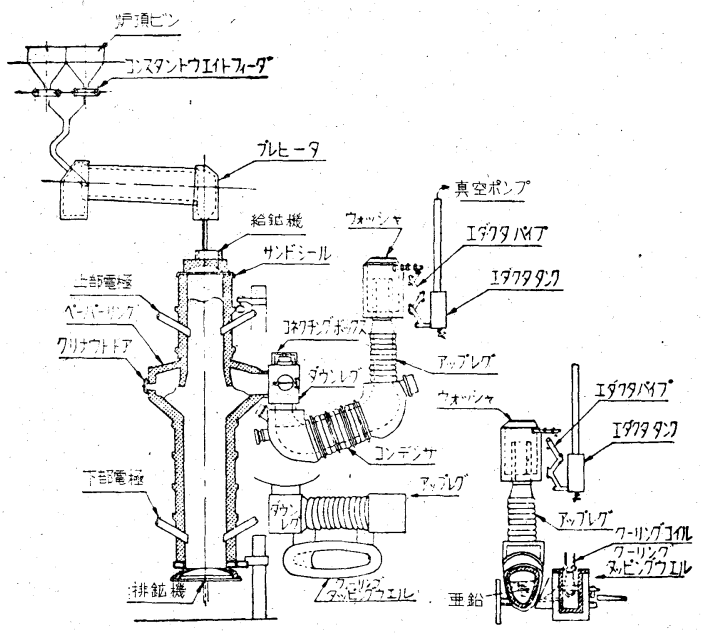

第1図 電熱蒸留系統図
中の亜鉛含有率は，おおむね56 58\%で，粒度は10 25 $\mathrm{mm}$ m゙55 65\%，-10 $\mathrm{mm}$ が35 45\%で，コークスの粒 度は 10 24mmが80 85\%，-10mmが15 20\%程度で ある。

装入量, 電極長さは炉況に最も影響し, 適正な炉内温 度分布を維持するためこれらの要因を炉況に応して調整 している。

シンターとコークスは, 炉頂ビンからコンスタントウ ェートフィーダで別々に切り出し，プレヒータで混合し ながらCOガスまたは重油の自動制御方式で約 800 850 ${ }^{\circ} \mathrm{C}$ 亿予熱して給鉱機で電炉内人装入する。装入物は，電 炉上部および下部に挿入してある電極間に電気を通ずる ことによつて加熱されるが，電炉が抵抗式電熱炉である ことから，炉内の温度分布は電流分布と同様と考えても よく, 炉内温度は炉壁部で約 $900^{\circ} \mathrm{C}$, 中心部では $1,400^{\circ} \mathrm{C}$ 以上で，装入物を熔融しないことが電熱法の特徵ともい える。なお，電炉は操業当初の 1 号電炉から 4 号電炉ま では 4 極炉であつたが，5,6 号炉の増設を機会に全炉を 6 極炉に改造し，投入電力も 4 極炉時代には 1,600 $1,800 \mathrm{~kW}$ であつたものを 6 極炉への改造や，1極当り の電力を上げたことなどによつて現在では， $4,800 \mathrm{~kW}$ なつている。その結果, 第 4 表に示したように 1 炉 1 日 当りの生産量は $13 \mathrm{t}$ 程度から逐次上昇して現在では $38 . \mathrm{t}$ に達している。

第 4 表 年度別の電炉 1 基 1 日当り生産量の推移

\begin{tabular}{l|l|l|l|l|l|l|l|l|l|l|l|l|l}
\hline \hline 年 度 & 30 & 31 & 32 & 33 & 34 & 35 & 36 & 37 & 38 & 39 & 40 & 41 & 42 \\
\hline 生虐 量 & 10.8 & 13.2 & 13.1 & 14.3 & 15.4 & 17.9 & 20.625 .4 & 25.5 & 27.7 & 27.9 & 29.4 & 38.0 \\
\hline
\end{tabular}

炉内で発生した亜鉛蒸気と一酸化炭素は，ベーパーリ ングに集まり真空ポンプの吸引によつてコンデンサへ導 かれ，ここで亜鉛蒸気が凝縮して熔体亜鉛となる。コン デンサおよびタッピングウェルには常時約 $35 \mathrm{t}$ の熔体亜 鉛が入つており，炉から出た亜鉛蒸気が凝縮してこの熔 体亜鉛の量が増加するにしたがつて吸引真空度が上昇す るので，限界圧力になるごとに熔体亜鉛をタッピングウ エルから抜き出している。コンデンサ内の湯温は，約 $500^{\circ} \mathrm{C}$ に保たれるが，この温度保持はコンデンサ外壁か らの熱放散とタッピングウェル内の水冷管によつて調節 している。タッピングウェルから抜き出した熔体亜鉛 は，脱鉛炉で脱鉛，脱鉄したのち自動連続鋳造機で 1 枚 $25 \mathrm{~kg}$ の型亜鉊に鋳造され製品（第 5 表）となる。

製品は，蒸留亜鉛地金 1 種で昭和 35 年 5 月に J I S 表 示許可を受けている。

第 5 表 蒸留亜鉛成分分析例

\begin{tabular}{c|c|c|c|c}
\hline 成 分 & $\mathrm{Zn}$ & $\mathrm{Pb}$ & $\mathrm{Fe}$ & $\mathrm{Cd}$ \\
\hline$\%$ & 98.9 & 1.05 & 0.01 & 0.05 \\
\hline
\end{tabular}


一方，COガスはわずかな未凝縮亚鉛とともにコンデ ンサに連結してあるウォッシャ拉よびエダクターをとお りながら洗浄, 冷却され, 真空ポンプの排気となり,こ れをさらに圧縮機で昇圧して使用個所へ圧送している。

洗浄水中に捕収した未凝縮睘鉛は, シックナで亜鉛末 として回収し，焼結工程へ繰り返している。

蒸留残さいは，炉底の排鉣機から排出されるが，この 排さい中には亜鉊がほとんど揮発したもの，揮発不充分 なもの，炉鉄，コークス等が含まれ，これらをふるい分 け, 磁選, 空気選別等で焼結工程への繰り返し物, 繰り 返しコークス，炉鉄，廃莗さい(第6 表)とに分離する。 炉鉄中には金, 銀, 銅のほとんどが濃縮し，銅量にして 月当り約 $100 \mathrm{t}$ で，これは社内の日立および佐賀関製錬 所に送り銅原料の一部としている。

第6 表 炉鉄および廃衰さいの主成分例

\begin{tabular}{|c|c|c|c|c|c|c|}
\hline & $\mathrm{Zn}$ & $\mathrm{Cu}$ & $\mathrm{Fe}$ & C & $\mathrm{Au}$ & $\mathrm{Ag}$ \\
\hline $\begin{array}{l}\text { 炉 鉄 } \\
\text { 廃榱さい }\end{array}$ & $\begin{array}{l}2.0^{\circ} \\
9.9\end{array}$ & $\begin{array}{l}7.0 \\
0.5\end{array}$ & $\begin{array}{l}56.8^{\%} \\
10.5\end{array}$ & $2.5^{\%}$ & $\begin{array}{l}7.7^{g / t} \\
0.7^{2}\end{array}$ & $\begin{array}{c}\mathrm{g} / \mathrm{t} \\
1 ; 306 \\
183\end{array}$ \\
\hline
\end{tabular}

以上蒸留部門の概略について述べたが，創業以来の主 要成績を示せば第 7 表のとおりである。

第 7 表 蒸留部門の年度別主要成績の推移

\begin{tabular}{c|c|c|c|c}
\hline 年度別 & 生 産 量 $(\mathrm{t})$ & $\begin{array}{c}\text { 炬電力原単位 } \\
(\mathrm{kWh} / \mathrm{t})\end{array}$ & $\begin{array}{c}\text { 粒Z } \\
\text { 単位 }(\mathrm{kg} / \mathrm{t})\end{array}$ & 採 収 率 $(\%)$ \\
\hline 30 & 6,154 & 3,284 & 731 & 81.8 \\
31 & 9,760 & 3,022 & 676 & 84.6 \\
32 & 12,070 & 2,817 & 581 & 87.9 \\
33 & 12,996 & 2,584 & 569 & 91.1 \\
34 & 17,221 & 2,692 & 497 & 92.7 \\
35 & 21,263 & 2,718 & 495 & 93.0 \\
36 & 29,115 & 2,809 & 526 & 91.1 \\
37 & 29,840 & 2,609 & 480 & 92.6 \\
38 & 45,970 & 2,621 & 495 & 92.2 \\
39 & 54,542 & 2,781 & 490 & 93.7 \\
40 & 61,209 & 2,805 & 490 & 95.1 \\
41 & 74,068 & 2,767 & 440 & 96.3 \\
\hline
\end{tabular}

\section{3. 精留・合金部門}

当所の最純亜鉛生産計画は，4号電炉が完成して常時 3 炬操業となつた昭和 34 年の後半から始められ, 当時定 評があつたニュージャージー・ジンク社と, 開発されて
まもなかつたアメリカン・メタル・クライマックス社の 精留方式について検討がなされたが，現地調查の結果， 三ュージャージ一法を採用することに決定し，35年 9 月 にノウハウ購入契約を締結した。翌36年 7 月には，精留 技術の習得のため当所から 3 名の技術者が派遣された。

建設は 37 年 3 月に始められ，38年 3 月に鉛塔 2 基と力 ドミ塔 1 基からなる精留工場が完成し，值ちに操業に入 つた。スタートに当つてはニュージャージーから 2 名の 技術者を招いて指導を受け, 順調にスタートした。以来, 逐次設備を増強して現在では $3,600 \mathrm{t}$ の生産能力をもつ にいたつた。

製品は J I S 規格の最純亜鉛に相当し，昭和38年11月 に J I S 表示許可を受けている。

ニュージャージーの立型亜鉛精留方式（第 2 図）は， 原料亜鉛中に含まれている各金属間の沸点の差を利用し て不純金属を除去精製する方法で，当所の場合原料は電 炉工場で生産される蒸留亜鉛である。

原料は熔体のまま電炬工場からレードルで運ばれ，少 プライポットに装入される。

鉛塔は，カーボランダム製のトレイで組み立てられ， 下部の約半分は燃焼室の内部にあり, 燃焼室では電炉工 場で発生するCOガスを燃焼して約 $1,200^{\circ} \mathrm{C}$ に保たれる。 サプライポットから供給される原料亜鉛は, 鉛塔トレイ のほぼ中央部から連続的に装入され, 燃焼室内のトレイ で大部分の亜鉛はカドミウムとともに蒸気となり，一部 は，未蒸発のまま塔内を流下する。鉛と鉄は，この中に 濃縮され脱鉛炉で除かれたのちサプライポットに繰り返 される。鉛塔で発生した亜鉛蒸気は, 塔の横にあるコン デンサで凝縮され熔体でカドミ塔に流入する。

カドミ塔は, 鉛塔とほぼ同じ装置で塔の頂部にコンデ ンサがあり，その横にキャニスタが設けられている。カ ドミ塔では鉛塔と全く同様に，沸点の低いカドミウムを 揮発してキャ、ニスタで捕収し，カドミウムよりも沸点の 高い亜鉛は塔内を流下して製品ポットに入り，自動連続 鋳造機で 1 枚 $25 \mathrm{~kg}$ の型亜鉛に鋳造され製品となる。

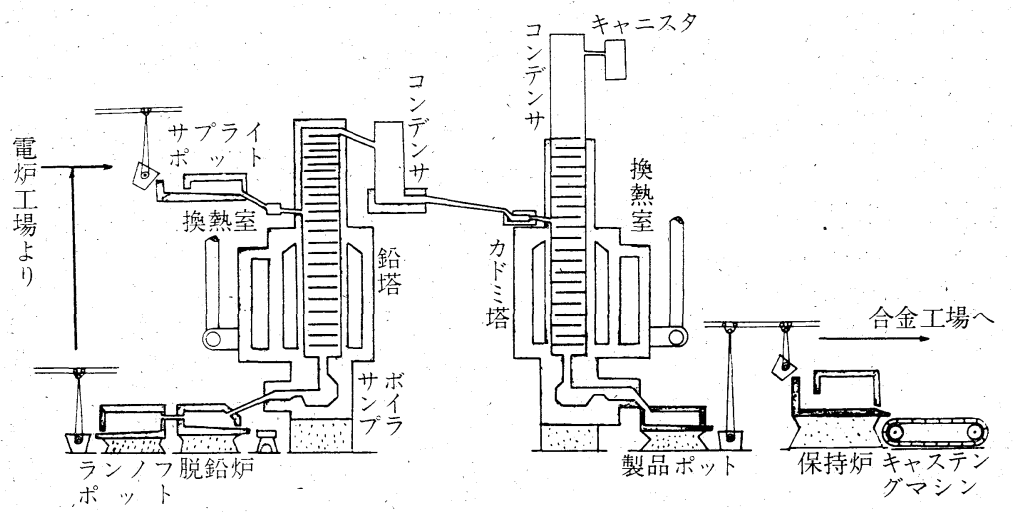

第 2 図

精留系統図 
以上のような工程で最純带鉛が生産されるが，精留装 置の能力は鉛塔 2 基, カドミ塔 1 基で, 月当り $1,360 \mathrm{t}$, その純度は99. 997 99. 998\%で非常に安定した品質の最 純亜鉛が生産される。

最純亜鉛の生産によつて需要が拉大し, 当所において もダイカスト用亜鉛合金塊の製造が計画され，38年 6 月 に小規模ながら月当り $50 \mathrm{t}$ の試験生産が開始された。続 いて 8 月に本工場の建設に着手して11月に完成し，月当 り $200 \mathrm{t}$ の操業を開始した。また，合金工場の建設と併 行してメッキ用业鉛陽極の製造設備も進められ，38年6 月に完成して生産を開始した。

メッキ用アノードとしては，最純亜鉛を原料とした「 最純アノード」と，特殊配合の「クロベアノード」その 他で，クロベアノードは，メッキ槽内の亜鉊濃度または M比を一定に維持することができその調節も容易であ る。また，青化ソーダの補給がほとんど不要で液をくみ 出す必要もなく, 槽内に扔ける自然溶解の心配がない等 の特色をもつたものである。

現在は，低周波誘導炉 3 基と電熱炉 3 基でダイカスト 用合金塊約 $900 \mathrm{t}$ と陽極類を約 $100 \mathrm{t}$ 生産している。なお ダイカスト用亜鉛合金塊については 1 種，2種とも昭和 39年 7 月にJ I S 表示許可を受けている。

\section{4. カドミウム部門}

当所は, まつたくの最小規模から出発したため, カド

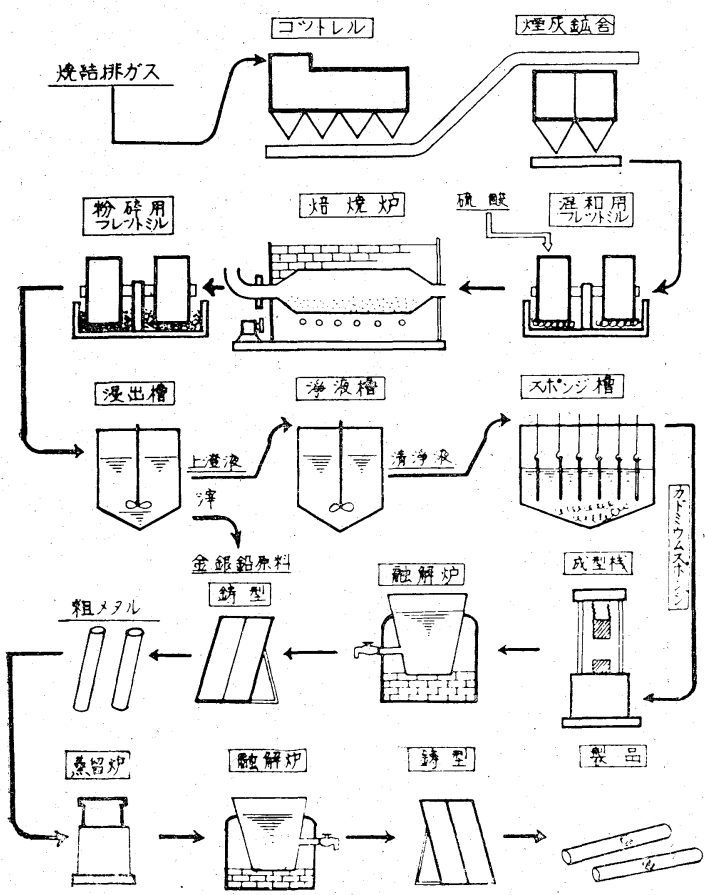

第3 図・カドミウム製鍊系統図
ミウムの回収設備をもたずに数年間を過したが，その間 に回收に関する試験研究を続け，技術的に一応の確信を 得たので，遺利の回収抒よび公害対策の一環として昭和 35 年 4 月にカドミウム工場の建設に入り，36年 3 月に完 成するとともに操業を開始した。生産能力は月当り $6 \mathrm{t}$ で出発し，製鍊方式は当所独自の減圧蒸留法で当社の特 許となつている。

工程は大別してばい焼工程, 浸出・浄液・置換工程, 蒸留工程（第 3 図）とからなり，次にその概略について 述べる。

燒結工程のコットレルで捕集したカドミウム含有率約 10\%のダストに，硫酸を添加して回転式電熱ばい焼炉で ばい焼し，カドミウムを選択的に硫酸カドミウムとした のち温水で浸出・浄液を行ない, 液中のカドミウムを亜 鉛板で置換してスポンジカドミウムとする。次にこのス ポンジカドミウムを加圧成型して熔解し, 粗メタルとす る。粗メタルは減圧蒸留炉で蒸留され, 微量の不純物を 除去したのち，ふたたび熔解して 1 本 $1 \mathrm{~kg}$ のペンシル カドミウムに鋳造する。

製品は極めて純度が高く，99.998\%以上で J I S 規格 のカドミウム地金 1 種を大幅に上回っている。な押，力 ドミウムについても昭和 38 年 2 月に 1 種の J I S 表示許 可を受けている。

その後の蒸留亜鉛生産量の拡大にともなつて, カドミ ウム工場も増強され，現在では約 $20 \mathrm{t}$ のカドミウムを生 産している。

\section{5. 結 言}

以上三日市製錬所における創業以来最近にいたるまで の操業の概要について述べた。同業他社に比べて創業の 日が浅い当所の今日の発展は, 戦後の鉄鋼業界の驚異的 な進歩に支えられるという幸運があつたとはいえ，亜鉛 製錬所として当所の設立を計画した首脳部が，当時の米 国亜鉛市場の動向から，わが国将来の亜鉛鉄板の伸びを 見越して，在来の製錬方式に比べて採收率および生産性 が高く，建設費が安い抵抗電熱式連続亜鉛蒸留法を採用 した卓見と, 北陸特有の粘り強さと, 勤労意欲旺盛で協 調性に富む優秀な従業員に恵まれたこと，また，操業の 早期安定化と固有技術の向上ならびに新製品開発のため に各種管理技術が早期かつ積極的に活用されたことなど が主因と考える。その結果, 操業もおおむ称軌道に乗つ た昭和 32 年当時に比へて, 当所 1 人当りの生産量は約 3 倍, 1 炉当りの生産量についても 2 倍に達し, コスト面 についても主要製品である蒸留带鉛に例をとると逐年電 力費, 人件費, 物品費などの大幅な值上りがあつたに安 かかわらず生産原価は約70\%に低下している。

また，現在当所の製品はJ I S規格に対して 5 シグマ以 
上の余裕をもち，バラツキの少ないきわめて安定した製 品孛生産している。

一方, 安全成績については創業初期はきわめて悪く, 度数率13.8，強度率0.14であつたが，毎年休みない設備 の増強にもかかわらず逐年向上し, 昭和 41 年度では度数 率2.91, 強度率0.025を示し，これらのいずれをみても 一応所期の目的を達していると考光ている。

しかしながら亜鉛業界の前途注，42年度からの完全自
由化によつて世界的な生産過剩による激烈な企業競争が 予想され，これに対処するための今後の課題は，固有技 術の向上はもらろん設備の大型化と自動制御化ならびに 新技術の開発に一段の努力を傾注し，少数精鋭による利 潤の追究を図りたい。

おわりにの発み当所発展途上汸抒いて, 種々ご指導を いただいた学界の各位と, 関係諸先督のご苦労に対し本 稿を借りて深謝申し上げる。

\title{
住鉱アイ・エス・ピ一播磨工場における亜鉛・鉛製錬
}

Zinc and Lead Smelting at Harima Work of Sumikō I.S.P. Co., Ltd.

\author{
正会員富 沢宣 成* \\ Senjō TOMIZAWA
}

\section{1. 緒言}

住鉣アイ・エス・ピ一株式会社は住友金属鉱山株式会 社，住友商事株式会社㧍よび製鉄化学工業株式会社の共 同出資により資本金 4 億円（昭和 42 年 9 月現在 10 億円） で昭和39年 7 月 10 日に設立された会社で, I.S.P. 法に よる亜鉛・鉛の同時製鍊ならびにこれに付帯する事業を 行ならことを目的としている。出資比率は住友金属鉱山 株式会社 $55 \%$ ，住友商事株式会社 $35 \%$, 製鉄化学工業株 式会社 $10 \%$ である。

製錬所浜庫県加古郡播磨町宮西の製鉄化学工業株式 会社別府製造所内の一隅 (敷地約 $26,500 \mathrm{~m}^{2}$ ) に所在し， 別府港の西の一角に位置する。製錬所の建設沼和39年 11月から着手され昭和 41 年 4 月精留工場の一部を残し完 成, 翌 5 月熔鉱炉炏入が行なわ玌た。以来順調に操業 が続けられ現在にいたつている。この設備による生産能 力は月産再鉛 $3,500 \mathrm{t}$, 電気鉛 $1,500 \mathrm{t}$ である。建設費は
建物, 機械装置, 動力, 輸送, 用水, 廃水, 公害防止設 備，社宅等で約 30 億円に達した。製錬所社員は工場長以 下約 260 名で基幹要員は住友金属鉱山株式会社より派遣 されている。

\section{2. 操業開始にいたるまでの経緯}

住友金属鉱山株式会社沼昭和 12 年頃よりすでに亜鉛製 錬に注目し，昭和 14 年 16年頃に注湿式法による製錬の 基礎ならびに中間規模試験等を行なつた時期もあつたが 国内に打ける原料鉣石の充分なる確保にいたらずまた 第 2 次世界大戦への突入のため一旦中止した。戦後にお いてももちろん基礎研究を意らず，工業化への機会をい くどか考慮し，慎重な検討を行なつてきた。たまたま昭 和33年にS. W. K. Morganの論文 “The Production of Zinc in a Blast Furnace" (Bulletin of the Institute Mining and Metallurgy 1957)に接して当時まだAvonmouth における中閒工業の段階にあつた I.S.P. 法，す

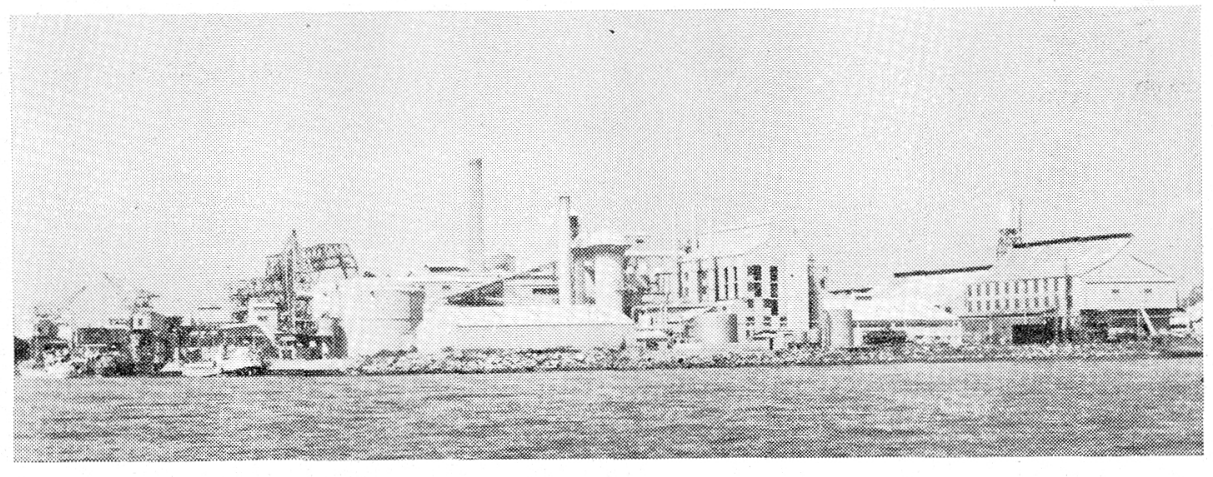

